\title{
PENGEMBANGAN SISTEM INFORMASI PROSES BELAJAR MENGAJAR ONLINE DENGAN MENGGUNAKAN METODE PEMBELAJARAN STUDENT CENTERED LEARNING (SCL)
}

\author{
Budi Harijanto ${ }^{1}$, Deddy Kusbianto P. ${ }^{2}$, Berlian Puspa Nova ${ }^{3}$ \\ 1,2,3 Program Studi Teknik Informatika, Jurusan Teknologi Informasi, Politeknik Negeri Malang \\ budi.hijet@gmail.com, ${ }^{2}$ deddykusbianto@gmail.com, ${ }^{3}$ berliankittyra@gmail.com
}

\begin{abstract}
Abstrak
Sistem informasi proses belajar mengajar online merupakan sistem pendidikan yang menggunakan aplikasi elektronik untuk mendukung pengembangan kegiatan belajar mengajar dengan media internet. Sistem Informasi ini memungkinkan terjadinya proses pendidikan tanpa melalui tatap muka langsung. Sistem informasi proses belajar mengajar online dengan menggunakan metode pembelajaran student centered learning di Politeknik Negeri Malang ini diterapkan pada Program Studi Teknik Informatika untuk memudahkan komunikasi antara dosen dan mahasiswa. Perhitungan dalam penerapan Simple Additive Weighting untuk mendapatkan nilai keaktifan mahasiswa memiliki 4 kriteria yaitu presentasi, bertanya, menjawab, praktikum. Dalam uji coba penerapan Simple Additive Weighting ke dalam sistem belajar mengajar online ini dengan membandingkan hasil output sistem dan hasil pakar memiliki tingkat akurasi mencapai 100\%. Sistem ini dirancang dan diimplementasikan dengan menggunakan PHP, MySQL, HTML, CSS, JavaScript dan Bootstrap. Sistem ini juga telah di uji coba oleh beberapa user dan hasilnya dapat disimpulkan bahwa aplikasi ini dapat membantu dosen dan mahasiswa berinteraksi secara online dalam kegiatan belajar mengajar.
\end{abstract}

Kata Kunci: Sistem Informasi, Proses Belajar Mengajar Online, Student Centered Learning

\section{Pendahuluan}

Perkembangan teknologi informasi yang semakin maju, sekarang ini menjadi kebutuhan akan suatu konsep dan mekanisme belajar mengajar berbasis teknologi informasi yang menjadi tidak terelakkan lagi. Konsep yang dikenal dengan sebutan proses belajar mengajar online ini membawa pengaruh terjadinya proses transformasi pendidikan konvensional ke bentuk digital, baik secara isi dan sistemnya. Sistem informasi proses belajar mengajar online adalah sistem pendidikan yang menggunakan aplikasi elektronik untuk mendukung pengembangan kegiatan belajar mengajar dengan media internet atau media jaringan komputer lain. Sistem informasi ini memungkinkan terjadinya proses pendidikan tanpa melalui tatap muka langsung dan pengembangan ilmu pengetahuan kepada mahasiswa bisa dilakukan dengan mudah.

Dalam penelitian sebelumnya yang dilakukan oleh Berlian Puspa Nova dan Laisa Amalin (2016) yang berjudul Pengembangan Sistem Informasi Proses Belajar Mengajar Online Berdasarkan Sistem Penjaminan Mutu Internal yang menghasilkan sebuah sistem pendukung proses belajar mengajar online yang masih dilakukan secara konvensional. ${ }^{[1]}$ Pembelajaran konvensional adalah dosen menjadi pusatnya sedangkan mahasiswa hanya menerima materi dan tugas yang diberikan. Dari paparan penelitian yang telah dilakukan sebelumnya, maka pada penelitian ini akan dibuat Pengembangan Sistem Informasi Proses Belajar Mengajar Online Dengan Menggunakan Metode Simple Addittive Weighting Pada Pembelajaran Student Centered Learning dimana dalam sistem ini mahasiswa harus aktif dalam hal menjelaskan materi, presentasi, mengikuti praktikum yang diberikan oleh dosen, dan mengerjakan tugas yang telah diberikan oleh dosen, sehingga dosen hanya mengevaluasi dan menilai apa yang telah dikerjakan oleh mahasiswa.

Melalui sistem informasi proses belajar mengajar online tersebut diharapkan dapat membantu para dosen berprofesional yang banyak kegiatan diluar jam mengajar perkuliahan dalam memperbaiki efektivitas dan efisiensi proses pembelajaran serta membantu dalam pencapaian tujuan-tujuan pembelajaran.

Selain itu, mahasiswa diharapkan dapat lebih mudah memperoleh informasi-informasi tentang pembelajaran yang diikuti sehingga dapat lebih giat dalam mengikuti aktifitas belajar. Salah satu bentuk pemanfaatan teknologi informasi dan komunikasi dalam pendidikan adalah dengan adanya proses belajar mengajar online. Sistem informasi ini memanfaatkan jasa teknologi elektronik yang memungkinkan dosen dan mahasiswa dapat berkomunikasi dengan mudah tanpa dibatasi ruang dan waktu. Perencanaan ini menggunakan metode pembelajaran. 
Metode pembelajaran student centered learning ini bertujuan untuk mengetahui keaktifan mahasiswa dalam proses belajar. Dalam penelitian ini dibuat sistem informasi belajar mengajar dengan menggunakan metode simple additive weighting yang digunakan untuk menentukan tingkat keaktifan mahasiswa. Penentuan keaktifan mahasiswa memiliki empat kriteria yaitu presentasi, bertanya, menjawab dan praktikum. Dengan menggunakan metode simple additive weighting dapat mengetahui tingkat keaktifan mahasiswa dari hasil rangking.

\section{Kajian Pustaka}

\subsection{Student Centered Learning (SCL)}

Student Centered Learning (SCL) adalah strategi pembelajaran yang menempatkan mahasiswa sebagai subyek/ peserta didik yang aktif dan mandiri, dengan kondisi psikologi sebagai adult learner, bertanggung jawab sepenuhnya atas pembelajarannya, serta mampu belajar beyond the classroom. Dengan prinsip-prinsip ini maka para mahasiswa diharapkan memiliki dan menghayati jiwa life-long learner serta menguasai hard skills dan soft skills yang saling mendukung. Di sisi lain, para dosen beralih fungsi menjadi fasilitator, termasuk sebagai mitra pembelajaran, tidak lagi sebagai sumber pengetahuan utama. Secara operasional, di dalam student centered learning para mahasiswa memiliki keleluasaan untuk mengembangkan segenap potensinya (cipta, karsa dan rasa), mengeksplorasi bidang/ ilmu yang diminatinya, membangun pengetahuan serta kemudian mencapai kompetensinya melalui proses pembelajaran aktif, interaktif, kolaboratif, kooperatif, kontekstual dan mandiri. Keleluasaan para mahasiswa ini difasilitasi oleh dosen yang menerapkan "Patrap Tri Loka" secara utuh (sebagaimana telah diketahui oleh para pendidik di Indonesia, yaitu "ing ngarsa sung tuladha, ing madya mangun karsa, tut wuri handayani").

Bahwa Undang-Undang Republik Indonesia nomor 20 Tahun 2003 tentang Sistem Pendidikan Nasional mengisyaratkan adanya karakteristik student centered learning dan "Patrap Tri Loka". Di dalam Bab III pasal 4 ayat (3) terdapat ketentuan tentang penyelenggaraan pendidikan, "Pendidikan diselenggarakan sebagai suatu proses pembudayaan dan pemberdayaan peserta didik yang berlangsung sepanjang hayat". Selanjutnya dalam pasal 4 ayat (4) terdapat ketentuan "Pendidikan diselenggarakan dengan memberi keteladanan, membangun kemauan, dan mengembangkan kreativitas peserta didik dalam proses pembelajaran".

\section{a. Pembelajaran Aktif}

Secara operasional, pembelajaran aktif (active learn-ing) dapat didefinisikan "Suatu aktivitas instruksional yang melibatkan para mahasiswa di dalam mengerjakan berbagai hal dan berpikir tentang apa yang sedang mereka kerjakan". Pembelajaran aktif berlangsung ketika para mahasiswa diberi kesempatan untuk lebih berinteraksi dengan teman sesama mahasiswa maupun dengan dosen perihal pokok bahasan yang sedang dihadapinya, mengembangkan pengetahuan dan bukan sekedar menerima informasi dari dosen. Di dalam suasana pembelajaran aktif maka dosen bertindak sebagai faslitator, bukan mendikte para mahasiswa. Pada hakekatnya pembelajaran aktif (mentally not physically) memerlukan upaya intelektual, analisis, sintesis dan evaluasi, serta meningkatkan kemampuan mahasiswa dalam hal asimilasi dan aplikasi pengetahuan. Sasaran pembelajaran aktif adalah pengembangan keterampilan berpikir, bukan pemindahan informasi.

\section{b. Pembelajaran Interaktif}

Interaksi dapat terjadi dalam berbagai bentuk yang berbeda, antara lain antara mahasiswa dengan materi pembelajaran, antara mahasiswa dengan aktivitas pembelajaran, antara mahasiswa dengan dosen/ fasilitator, dan antar mahasiswa. Di dalam pembelajaran interaktif maka setiap mahasiswa harus mengerjakan sesuatu, sesuai dengan pengetahuan atau materi yang sedang dipelajarinya. Interaksi dengan content berarti terjadi proses aktif dan mengkombinasikan content dengan pengetahuan dan pengalaman yang telah dimilikinya (prior knowledge/ experience).

Memperhatikan pemahaman dasar tentang interaksi maka pembelajaran merupakan suatu aktivitas sosial. Hal ini mengembangkan pengertian bahwa pembelajaran bukan sekedar interaksi tatap muka. Interaksi sosial terjadi di antara kelompok orang dengan menggunakan berbagai media atau alat, misalnya telepon, faksimili, surat elektronik, surat pos dan media lainnya yang menggunakan teknologi canggih. Interaksi sosial dapat bersifat bebas dari batas waktu dan tempat.

\section{c. Pembelajaran Mandiri}

Pembelajaran mandiri (self-directed learning) adalah suatu pendekatan pembelajaran yang berpusat pada mahasiswa (student-centred approach) di mana proses dan pengalaman belajar diatur dan dikontrol oleh mahasiswa sendiri. Para mahasiswa memutuskan sendiri tentang "bagaimana, di mana, dan kapan belajar tentang suatu hal yang mereka anggap merupakan hal yang penting”. Di dalam pembelajaran mandiri para mahasiswa berlatih untuk mengidentifikasi berbagai masalah yang perlu dipelajari lebih jauh (investigation), tahu di mana harus mencari sumber-sumber belajar yang berkaitan dengan masalah tadi, mampu menentukan prioritas dan merancang penelusuran sumber belajar, mampu mempelajari materi yang ada di dalam sumber 
belajar tadi, dan kemudian menghubungkan informasi yang telah terkumpul dengan pokok bahasan yang sedang dipelajarinya.

Ditinjau dari aspek operasional pembelajaran mandiri diartikan sebagai kemampuan seseorang dalam hal metode dan disiplin, logika dan analitika, kolaboratif dan interdependen, sifat ingin tahu dan terbuka, kreatif, termotivasi, persisten dan bertanggung jawab, percaya diri dan mampu untuk belajar, serta reflektif dan sadar diri. Untuk dapat memiliki sifat-sifat yang kompleks tadi, mahasiswa harus memperoleh kesempatan guna mengembangkan dan mempraktikkan keterampilan dan kecakapannya yang mengarah pada peningkatan pembelajaran mandiri. Keterampilan dan kecakapan tadi meliputi kemampuan mengajukan pertanyaan, mampu untuk menilai secara kritis setiap informasi baru, mengidentifikasi kesenjangan pengetahuan dan keterampilan diri sendiri, dan kemampuan untuk merefleksikan secara kritis proses pembelajaran dan outcome yang diperoleh.

Kemandirian (self-direction) merupakan konsep organisasi untuk pendidikan tinggi; dengan demikian kemandirian berkaitan erat dengan politik pendidikan. Pembelajaran mandiri memiliki komitmen demokratis terhadap perubahan posisi dan peran para mahasiswa di mana mereka memegang kontrol yang lebih besar terhadap dirinya sendiri dalam hal konseptualisasi, perancangan, pelaksanaan, dan evaluasi belajar serta penetapan cara-cara pemanfaatan sumber belajar guna proses belajar lebih lanjut. Di samping itu, kemandirian selaras dengan perkembangan fisik, psikologi dan sosial mahasiswa yang masuk ke dalam alam dewasa. Secara ringkas dapat dikatakan bahwa kemandirian selaras dengan konsep adult-learner.

Karakteristik adult-learner meliputi selfdirected, life experience and knowledge, good oriented, relevance oriented, praktik dan mampu menghargai pendapat orang lain. Self-directed berarti memiliki kemampuan untuk mengatur dan mengelola kegiatannya, baik yang berkaitan dengan kegiatan akademik maupun nonakademik. Life experience \& knowledge berarti memiliki pengalaman pada jenjang sebelumnya, serta memiliki pengetahuan yang memadai untuk mencari tambahan pengetahuan baru sesuai dengan minatnya. Good oriented berarti memiliki kegiatan yang terarah pada tujuan sehingga perilakunya menjadi terarah pada tujuan yang hendak dicapai. Relevance oriented berarti dalam proses pembelajaran mahasiswa berorientasi pada relevansi antara materi yang dipelajari dengan minat studinya. Praktis berarti apa yang dipelajarinya dapat diaplikasikan dalam menunjang karirnya di masa yang akan datang.

\section{d. Pembelajaran Kolaboratif}

Pembelajaran kolaboratif (collaborative learning) pada hakekatnya merupakan pengalaman filosofis pribadi. Di dalam kelompok diskusi, tiaptiap individu berperan aktif, saling memberi kontribusi, saling menerima pendapat kawan dengan prasangka baik, saling menghargai kemampuan orang lain. Pembelajaran kolaboratif lebih menekankan saling berbagi pengalaman dan pendapat, dan bukan merupakan kompetisi di antara pembelajar.

Secara teknis, pembelajaran kolaboratif merupakan metode instruksional yang membuat mahasiswa dari berbagai macam latar belakang bekerjasama dalam kelompok kecil untuk mencapai tujuan pembelajaran secara umum. Para mahasiswa, berdasarkan pada konsensus yang dibangun sendiri oleh anggota kelompok, secara bersama-sama bertanggung jawab sepenuhnya atas proses pembelajaran yang mereka laksanakan. Dengan demikian keberhasilan seorang mahasiswa akan membantu keberhasilan kawannya.

Di dalam pembelajaran tradisional ada kepercayaan bahwa apabila mutu ditingkatkan maka biaya atau ongkos dengan sendirinya akan naik pula. Hal demikian ini tidak perlu terjadi di dalam pembelajaran kolaboratif, dengan menggunakan kolaborasi maka mutu pembelajaran akan ditingkatkan tanpa harus menaikkan ongkos produksi, atau malahan ongkos produksi secara simultan akan turun. Kunci pembelajaran bermutu adalah memaksimalkan partisipasi mahasiswa di dalam proses interaksi (interactive learning). Di dalam proses ini para mahasiswa secara bersamasama akan berpikir, bertukar pikiran atau beradu pendapat.

\section{e. Pembelajaran Kooperatif}

Kooperatif (cooperative learning) merupakan kelanjutan dari pembelajaran kolaboratif. Di dalam pembelajaran kooperatif kelompok mahasiswa akan memperoleh pengetahuan baru yang bermakna dengan mutu yang lebih baik, bersifat kontekstual dan relevan bila dibandingkan dengan pembelajaran individual atau independen. Sementara itu pada saat yang sama, setiap anggota kelompok di dalam pembelajaran kooperatif menunjukkan sikap positif, teguh pada pendiriannya tetapi tetap dalam kerangka kerjasama dan saling menghargai. ${ }^{[2]}$

\subsection{Metode Simple Additive Weight (SAW)}

Metode Simple Additive Weighting (SAW) merupakan metode penjumlahan terbobot. Konsep dasar metode SAW adalah mencari penjumlahan terbobot dari rating kinerja pada setiap alternatif pada semua kriteria. Metode SAW membutuhkan proses normalisasi matrik keputusan (X) ke suatu 
skala yang dapat diperbandingkan dengan semua rating alternatif yang ada. Metode SAW mengenal adanya 2 (dua) atribut yaitu kriteria keuntungan (benefit) dan kriteria biaya (cost). Perbedaan mendasar dari kedua kriteria ini adalah dalam pemilihan kriteria ketika mengambil keputusan.

Adapun langkah penyelesaian dalam menggunakannya adalah:

a. Menentukan alternatif, yaitu $\mathrm{A}_{\mathrm{i}}$

b. Menentukan kriteria yang akan dijadikan acuan dalam pengambilan keputusan, yaitu $\mathrm{C}_{\mathrm{j}}$.

c. Memberikan nilai rating kecocokan setiap alternatif pada setiap kriteria.

d. Menentukan bobot preferensi atau tingkat kepentingan (W) setiap kriteria.

$$
W=\left[W_{l}, W_{2}, W_{3}, \ldots, W_{j}\right]
$$

e. Membuat tabel rating kecocokan dari setiap alternatif pada setiap kriteria.

f. Membuat matrik keputusan (X) yang dibentuk dari tabel rating kecocokan dari setiap alternatif pada setiap kriteria. Nilai $\mathrm{X}$ setiap alternatif $\left(\mathrm{A}_{\mathrm{i}}\right)$ pada setiap kriteria $\left(\mathrm{C}_{\mathrm{j}}\right)$ yang sudah ditentukan, dimana, $i=1,2, \ldots m$ dan $j=1,2, \ldots n$.

$$
X=\left[\begin{array}{cccc}
x_{11} & x_{12} & \ldots & x_{1 j} \\
\cdot & \cdot & \cdot \\
x_{i 1} & x_{i 2} & \ldots & x_{i j}
\end{array}\right]
$$

g. Melakukan normalisasi matrik keputusan dengan cara menghitung nilai rating kinerja ternormalisasi (rij) dari alternatif Ai pada kriteria

$\mathrm{C}_{\mathrm{j}}$.

$$
r_{i j}=\left\{\begin{array}{l}
\frac{x_{i j}}{\operatorname{Max}_{i}\left(x_{i j}\right)} \\
\frac{\operatorname{Max}_{i} x_{i j}}{x_{i j}}
\end{array}\right.
$$

Keterangan :

a) Kriteria keuntungan apabila nilai memberikan keuntungan bagi pengambil keputusan, sebaliknya kriteria biaya apabila menimbulkan biaya bagi pengambil keputusan.

b) Apabila berupa kriteria keuntungan maka nilai dibagi dengan nilai dari setiap kolom, sedangkan untuk kriteria biaya, nilai dari setiap kolom dibagi dengan nilai $\mathrm{X}_{\mathrm{ij}}$.

h. Hasil dari nilai rating kinerja ternomalisasi $\left(\mathrm{r}_{\mathrm{ij}}\right)$ membentuk matrik ternormalisasi (R).

$$
R=\left[\begin{array}{ccc}
r_{11} & r_{12} \ldots & r_{1 j} \\
\cdot & \cdot & \cdot \\
r_{i 1} & r_{i 2} \ldots & r_{i j}
\end{array}\right]
$$

i. Hasil akhir nilai preferensi (Vi) diperoleh dari penjumlahan dari perkalian elemen baris matrik ternormalisasi (R) dengan bobot preferensi (W) yang bersesuaian elemen kolom matrik (W).

$$
V_{i}=\sum_{j=1}^{n} W_{j} r_{i j}
$$

Hasil perhitungan nilai $\mathrm{V}_{1}$ yang lebih besar menindikasilan nahwa alternatif $\mathrm{A}_{\mathrm{i}}$ merupakan alternatif terbaik Kusumadewi, S., dkk (2006).

Adapun kelebihan dari metode Simple Additive Weighting ( $S A W$ ) adalah sebagai berikut:

a. Menentukann nilai bobot untuk setiap atribut, kemudian dilanjutkan dengan proses perangkaian yang akan menyeleksi alternatif terbaik dari sejumlah alternatif.

b. Penilaian akan lebih tepat karena didasarkan pada nilai kriteria dari bobot preferensi yang sudah ditentukan.

c. Adanya perhitungan normalisasi matriks sesuai dengan nilai atribut (antara nilai benefit dan cost $){ }^{[3]}$

\section{Metode Penelitian}

\subsection{Metode Pengambilan Data}

Untuk dapat melakukan analisis yang baik, diperlukan data dan teori konsep dasar sehingga kebutuhan data sangat mutlak diperlukan. Adapun metode pengumpulan data dilakukan dengan cara:

a. Pengamatan Langsung

Melakukan pengamatan langsung supaya mengetahui alur yang saat ini sedang berjalan. Penulis juga mengumpulkan data berupa data nilai mahasiswa, data absensi mahasiswa, data dosen pengajar, dan data mata kuliah untuk melengkapi data pada perancangan aplikasi. Data tersebut diperoleh dari administrasi Program Studi Teknik Informatika di Politeknik Negeri Malang dengan cara melakukan pengamatan secara langsung.

b. Wawancara

Berdasarkan pengumpulan data dilakukan wawancara pada tanggal 9 Maret 2017 di Jurusan Teknologi Informasi dengan Bapak Ir. Deddy Kusbianto P., M.MKom selaku Ketua Program Studi Teknik Informatika membahas mengenai layanan yang akan dibuat. Layanan yang akan dibuat meliputi layanan registrasi, activity dosen, dan PBM (Proses Belajar Mengajar). Untuk dapat membuat layanan tersebut maka dibutuhkan data untuk mendukung pembuatan aplikasi pembelajaran meliputi data admin, data dosen, data mahasiswa, data kelas, data mata kuliah, dan data tugas.

c. Studi Literatur

Mengumpulkan dan mempelajari literatur, buku, artikel, dan sebagainya yang diperoleh dari perpustakaan, internet, dan sumber lainnya mengenai metode pembelajaran student centered 
learning dan materi-materi lain yang dibutuhkan dalam penyusunan laporan skripsi.

\subsection{Metode Pengolahan Data}

Perancangan desain sistem dapat menggunakan berbagai model, model yang digunakan untuk menggambarkan alur proses aplikasi pengembangan sistem infomasi proses belajar mengajar online dengan menggunakan metode student centered learning (SCL).

Berdasarkan pengumpulan data dilakukan wawancara pada tanggal 9 Maret 2017 di Jurusan Teknologi Informasi dengan Bapak Ir. Deddy Kusbianto P., M.MKom selaku Ketua Program Studi Teknik Informatika membahas mengenai layanan yang akan dibuat. Layanan yang akan di buat meliputi layanan registrasi, buka kelas, dan PBM. Untuk dapat membuat layanan tersebut maka dibutuhkan data untuk mendukung pembuatan aplikasi pembelajaran meliputi data admin, data dosen, data mahasiswa, data kelas, data mata kuliah, dan data tugas.

\subsection{WBS}

Berikut ini adalah Work Breakdown Structure dari aplikasi pembelajaran online yang ditunjukkan pada gambar 1 .

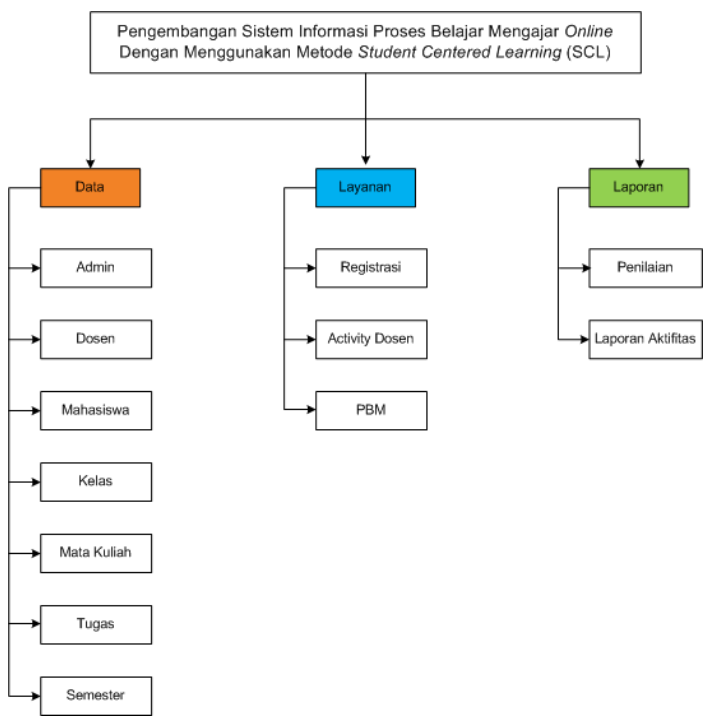

Gambar 1. Work Breakdown Structure

\subsection{DFD}

Berikut ini adalah Data Flow Diagram dari aplikasi pembelajaran online yang ditunjukkan pada gambar 2.

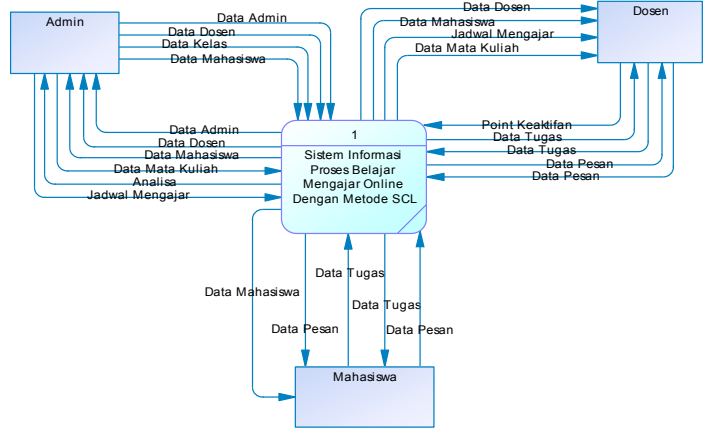

Gambar 2. Data Flow Diagram

\section{Hasil dan Pembahasan}

\subsection{Hasil}

Pada hasil basis data akan dijelaskan mengenai penerapan dari basis data yang digunakan pada sistem. Berdasarkan perancangan yang telah dilakukan, dibuat database yang berisi beberapa tabel seperti terlihat pada gambar 3 .

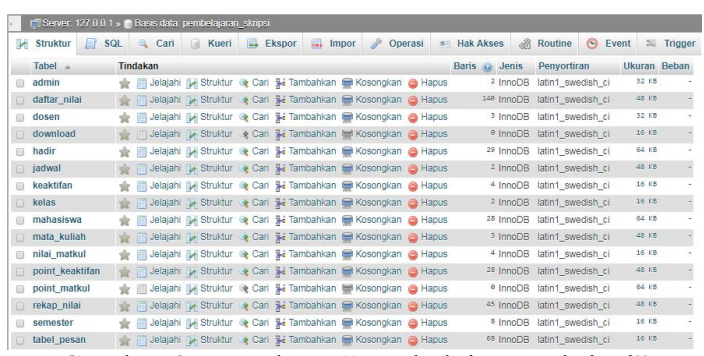

Gambar 3. Database "pembelajaran_skripsi”

Pada implementasi sistem akan dijabarkan implementasi dari aplikasi proses belajar mengajar online. Pada halaman awal proses belajar mengajar online ini terdapat menu kategori tiga user yang terdiri dari login admin, dosen, dan mahasiswa ditunjukkan pada gambar 4 .

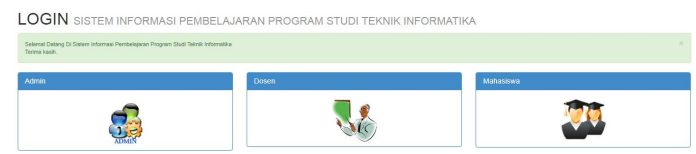

Gambar 4. Login User

Berikut merupakan halaman login tiap user ditunjukkan pada gambar 5 . 

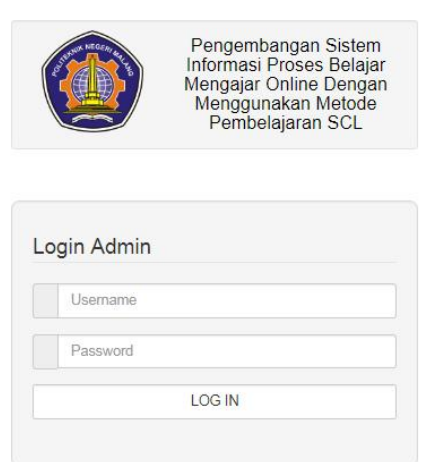

Gambar 5. Halaman Login Admin

Di bawah ini merupakan tampilan awal halaman login admin terdapat menu data admin, data dosen, data mahasiswa, jadwal mengajar, data tugas, data kelas, data mata kuliah, dan analisis ditunjukkan pada gambar 6 .
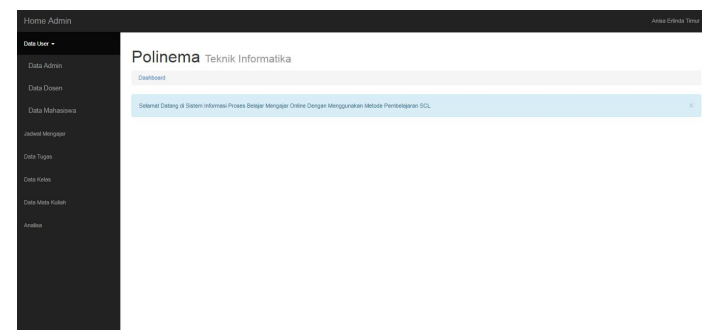

Gambar 6. Halaman Utama Admin

Di bawah ini merupakan tampilan analisa dari metode simple additive weighting ditunjukkan pada gambar 7.

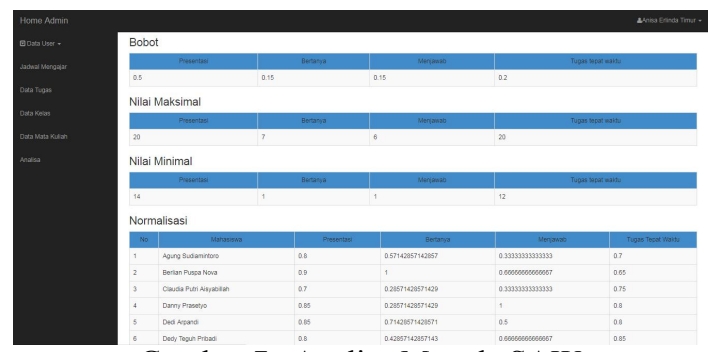

Gambar 7. Analisa Metode SAW

\subsection{Pembahasan}

Dari pengujian yang dilakukan, untuk pengujian fungsional dari setiap menu sudah berjalan dengan baik. Dilihat dari proses pengujian fungsional aplikasi proses belajar mengajar online ini berjalan sesuai dengan rancangan dan analisis yang telah dijelaskna pada tahap analisis kebutuhan.

Pengujian hasil sistem dengan microsoft excel akan di uji dengan menghitung nilai bobot menggunakan metode SAW sehingga menghasilkan perangkingan. Berikut merupakan perhitungan dengan metode SAW.
Tabel 1. Penilaian Kriteria

\begin{tabular}{|c|c|c|c|c|}
\hline Presentasi & Bertanya & Menjawab & Praktikum & Nilai \\
\hline 0 & 0 & 0 & 0 & 0 \\
$1-5$ & $1-5$ & $1-5$ & $1-5$ & 1 \\
$6-10$ & $6-10$ & $6-10$ & $6-10$ & 2 \\
$11-15$ & $11-15$ & $11-15$ & $11-15$ & 3 \\
$16-20$ & $16-20$ & $16-20$ & $16-20$ & 4 \\
\hline
\end{tabular}

Menentukan bobot preferensi atau tingkat kepentingan setiap kriteria yang di ambil dari buku pedoman program studi teknik informatika.

$$
\mathrm{W}=[0.5,0.15,0.15,0.2]
$$

Membuat rating kecocokan dari setiap alternative pada setiap kriteria.

Tabel 2. Alternatif dan Nilai

\begin{tabular}{|c|c|c|c|c|}
\hline \multirow{2}{*}{ Alternartif } & \multicolumn{4}{|c|}{ Kriteria } \\
\cline { 2 - 5 } & $\mathrm{C} 1$ & $\mathrm{C} 2$ & $\mathrm{C} 3$ & $\mathrm{C} 4$ \\
\hline A1 & 16 & 4 & 2 & 14 \\
\hline A2 & 18 & 7 & 4 & 13 \\
\hline A3 & 14 & 2 & 2 & 15 \\
\hline A4 & 17 & 2 & 6 & 16 \\
\hline A5 & 17 & 5 & 3 & 16 \\
\hline Bobot & 0.5 & 0.15 & 0.15 & 0.2 \\
\hline
\end{tabular}

Melakukan normalisasi matrik keputusan dengan cara menghitung nilai rating kinerja ternormalisasi.

Tabel 3. Perhitungan Normalisasi

\begin{tabular}{|c|c|c|c|c|}
\hline \multirow{2}{*}{ Alternartif } & \multicolumn{4}{|c|}{ Kriteria } \\
\cline { 2 - 5 } & $\mathrm{C} 1$ & $\mathrm{C} 2$ & $\mathrm{C} 3$ & $\mathrm{C} 4$ \\
\hline A1 & 0.8 & 0.5714 & 0.3333 & 0.7 \\
\hline A2 & 0.9 & 1 & 0.6667 & 0.65 \\
\hline A3 & 0.7 & 0.2857 & 0.3333 & 0.75 \\
\hline A4 & 0.85 & 0.2857 & 1 & 0.8 \\
\hline A5 & 0.85 & 0.7142 & 0.5 & 0.8 \\
\hline Bobot & 0.5 & 0.15 & 0.15 & 0.2 \\
\hline
\end{tabular}

Hasil akhir preferensi diperoleh dari penjumlahan dari perkalian elemen baris matrik ternormalisasi.

Tabel 4. Faktor Normalisasi dan Perangkingan

\begin{tabular}{|c|c|c|}
\hline Alternartif & $\begin{array}{c}\text { Faktor } \\
\text { Normalisasi }\end{array}$ & Peringkat \\
\hline A1 & 0.675714286 & 23 \\
\hline A2 & 0.83 & 6 \\
\hline A3 & 0.592857143 & 28 \\
\hline A4 & 0.777857143 & 11 \\
\hline A5 & 0.767142857 & 13 \\
\hline
\end{tabular}




\section{Kesimpulan}

Berdasarkan hasil yang diperoleh dalam pembuatan dan uji coba pembuatan Pengembangan Sistem Informasi Proses Belajar Mengajar Online Dengan Menggunakan Metode Pembelajaran Student Centered Learning (SCL) ini, maka dapat diambil beberapa kesimpulan yaitu sebagai berikut :

a. Aplikasi ini sudah sesuai dengan layanan yang dibutuhkan oleh user yang ada pada Politeknik Negeri Malang , karena sistem ini dapat membantu dalam penyampaian materi jarak dekat maupun jarak jauh kepada mahasiswa.

b. Dapat meningkatkan nilai keaktifan mahasiswa.

c. Dengan adanya layanan kirim pesan maka akan mempermudah komunikasi antara dosen dan mahasiswa apabila ingin konsultasi atau konsultasi hasil belajar mahasiswa kepada dosen.

d. Aplikasi ini mempermudah dalam penyampaian materi dari jarak jauh dan dapat meningkatkan keaktifan mahasiswa.

\section{Daftar Pustaka:}

Nova Berlian, Amalin Laisa. 2016. Pengembangan Sistem Informasi Proses Belajar Mengajar Online Berdasarkan Sistem Penjaminan Mutu Internal (SPMI). Malang.

Harsono, Dwiyanto D. 2005. Pembelajaran Berpusat Mahasiswa. Yogyakarta: Pusat Pengembangan Pendidikan Universitas Gadjah Mada, Aditya Media.

Ditjen Dikti Depdiknas. 2004. Tanya Jawab Seputar Unit dan Proses Pembelajaran di Perguruan Tinggi. Jakarta: Departemen Pendidikan Nasional.

Kusumadewi, Sri, dkk. 2006. Fuzzy Multi-Attributr Decision Making (Fuzzy MADM).

Yogyakarta: Graha Ilmu. 
Volume 4, Edisi 1, November 2017

$\mathbf{2 4} \mid \mathrm{H}$ a 1 a $\mathrm{m}$ a $n$ 